\title{
Enteric Methane Emission Estimates for the Zimbabwean Sanga Cattle Breeds of Tuli and Mashona
}

Showman Gwatibaya ( gwatibayashowman@yahoo.com )

Chinhoyi University of Technology https://orcid.org/0000-0001-8491-8510

Chrispen Murungweni

Chinhoyi University of Technology

Irvine Mpofu

Chinhoyi University of Technology

Raphael Jingura

Chinhoyi University of Technology

Accadius Tinarwo Tigere

Grassland Research Institute

Bosiwe Tererai

Makoholi Research Institute

\section{Research Article}

Keywords: methane, enteric fermentation, emission factor, conversion factor, Tier-1, Tier-2

Posted Date: November 1st, 2021

DOI: https://doi.org/10.21203/rs.3.rs-997248/v1

License: () (1) This work is licensed under a Creative Commons Attribution 4.0 International License.

Read Full License 


\section{Enteric methane emission estimates for the Zimbabwean Sanga}

\section{2 cattle breeds of Tuli and Mashona}

3 Showman Gwatibaya, ${ }^{\mathrm{a}},{ }^{*}$ Chrispen Murungweni, ${ }^{\text {a }}$ Irvine Mpofu, ${ }^{\text {a }}$ Raphael Jingura, ${ }^{\text {a }}$ Accadius

4 Tinarwo Tigere, ${ }^{b}$ Bosiwe Tererai ${ }^{c}$

$5{ }^{\text {a }}$ Department of Animal Production and Technology, Chinhoyi University of Technology

6 Off-Chirundu Road Private Bag 7724 Chinhoyi, Zimbabwe

7 b Grasslands Research Institute, Agricultural Research Innovation and Development

8 Directorate, Fifth Street Extension P O Box CY594 Causeway Harare Zimbabwe

9 c Makoholi Research Institute, Agricultural Research Innovation and Development

10 Directorate, Fifth Street Extension P O Box CY594 Causeway Harare Zimbabwe

11 * Correspondence: gwatibayashowman@yahoo.com or sgwatibaya@cut.ac.zw 


\section{Abstract}

22 The effectiveness of methane mitigation in ruminant livestock production systems depends on the accuracy of estimating methane emission factors and providing accurate emission inventories. Following the Paris Climate agreement, it is recommended that countries adopt the Tier-2 approach for estimating enteric methane emissions from ruminants instead of the Tier-1 approach currently used by most countries. This study sought to provide base line enteric methane emission estimates for the Tuli and Mashona Sanga cattle breeds in Zimbabwe using the IPCC Tier-2 model. Using animal characterization data collected from 412 cattle from Grasslands Research Institute and 406 cattle from Makoholi Research Institute, net energy requirements were estimated. From this and the estimate for digestibility, gross energy intake and dry matter intake were estimated. Gross energy intakes and the estimated methane conversion factor were used to estimate enteric methane emissions. Mean emission factors for Tuli were 45.1, 56, 28.5, 28.4, 20.6kg $\mathrm{CH}_{4} / \mathrm{h}$ ead/year for cows, bulls, heifers, steers and calves respectively. For Mashona, they were 47.8, 51.9, 29, 29.1 and $20.7 \mathrm{kgCH}_{4} / \mathrm{head} / \mathrm{year}$ for cows, bulls, heifers, steers and calves respectively. Generally, estimated Tier-2 emission factors were significantly different from the IPCC Tier-1 default emission factors. This study concluded that enteric methane emission factors estimated using the IPCC Tier-2 model offer insights into the controversial use of the default IPCC Tier-1 emission factors.

Key words: methane, enteric fermentation, emission factor, conversion factor, Tier-1,

\section{Tier-2}




\section{Introduction}

A significant portion of agricultural emissions in most developing countries come from ruminant livestock, which include cattle, sheep and goats (Abdelrahman and Lou, 2015, Gupta et al., 2018, Reisinger and Clark, 2018). The bulk of the emissions from ruminant livestock are in the form of methane produced through enteric fermentation. Cattle dominate ruminant livestock emissions in most developing countries especially in Sub-Saharan Africa (Bhatta et al., 2015). Globally enteric methane emissions account for $47 \%$ of the livestock sector emissions (de Haan, 2006, Henning, 2011, Mitloehner and Place, 2011) and cattle are a major contributor (Agrawal and Kamra, 2010, Allievi et al., 2019, Caro et al., 2014).

Methane production from ruminants takes place through enteric fermentation mainly in the reticulo-rumen as part of the normal digestive process through the activity of methanogens (Buccioni et al., 2015). The bulk of enteric methane (87 -90\%), is produced in the rumen and released into the atmosphere through eructation and belching (Pashaei et al., 2010). Besides being a potent greenhouse gas, enteric methane also represents an unproductive loss of dietary energy ranging from 3 to $12 \%$ of gross energy intake (Yan et al., 2000). The amount of methane produced through enteric fermentation depends on animal factors like breed, animal body size, animal metabolism, physiological state, animal activity, animal productivity levels, and feed factors like feed quality and the level of feed intake (Kumar et al., 2009, Shibata and Terada, 2010).

Due to methane's contribution to global warming (Etiope, 2012), it has become increasingly necessary to manage methane produced through enteric fermentation (Grossi et al., 2019). However, the effectiveness of methane mitigation techniques significantly depends on the accuracy of estimating ruminant enteric methane emission factors and providing accurate emission inventories (Herrero et al., 2016). In light of the foregoing, the Intergovernmental Panel on Climate Change (IPCC), has developed three different approaches for estimating 
enteric methane emissions (Penman et al., 2006). The three tiered approach is made up of Tier-1, Tier-2 and Tier-3 models with tier levels determining the level of detail and complexity (Eggleston et al., 2006, Hiraishi et al., 2014). Tier-1 estimates are default values derived from livestock data for livestock systems in developed countries and adjusted to fit different continental geographic regions (Bernoux and Wolf, 2017, FAO, 2015). By their nature, Tier-1 estimates cannot accommodate changes in emissions caused by changes to livestock production systems. Tier-2 estimates represent a substantial increase in precision of estimating enteric methane emissions because they are based on country specific livestock data. The Tier-3 estimates are high complexity estimates which are based on country specific models (Bannink et al., 2010, Bannink et al., 2011). The Tier-3 approach is based on the feeding system applied to each type of animal with the feed basket sufficiently defined (Eugène et al., 2019). It is therefore recommended that country specific emission factors for the major ruminant livestock species are developed using the more representative Tier-2 or Tier-3 approaches.

In Zimbabwe, the Tuli and Mashona are the dominant indigenous cattle breeds (Ramsay, 2010). The two breeds have been the most preferred among communal farmers because of their adaptability to the local climatic conditions (Gororo et al., 2017). With the possibility of an expansion of dry regions due to climate change, Mashona and Tuli are going to be more desirable for beef production in Zimbabwe. With their population likely to increase, there is a need to characterize their enteric methane emissions. Currently emissions from the livestock sector in Zimbabwe are based on the default IPCC Tier-1 emission factors (Svinurai et al., 2018). However recommendations are being made for developing countries to adopt the Tier2 approach in their enteric methane emission estimations.

The IPCC good-practice guidelines state that Tier-2 models should be used for key national greenhouse gas sources like cattle (Kelliher et al., 2009, Milne et al., 2014). Because of 
uncertainties associated with the use of Tier-1 emission factors (Azizi et al., 2017), it is important to develop country-specific Tier-2 emission factors for the major cattle breeds. To develop country specific enteric methane emission factors using the IPCC Tier-2 model, animal factors such as live weight, feed intake, feed digestibility and feed energy content are required (IPCC, 2006). The objective of this study was, therefore, to develop country specific baseline Tier-2 enteric methane emission estimates for the major Zimbabwean Sanga cattle breeds, Tuli and Mashona using country specific animal activity data.

\section{Materials and Methods}

\subsection{Research Site}

Animal activity and characterization data was collected from two agricultural research institutes run by the Ministry of Lands, Agriculture, Water, Fisheries, and Rural Resettlement under the Agricultural Research Innovation and Development Directorate. The two research Institutes are Grasslands Research Institute (GRI) located in the Mashonaland East Province, and Makoholi Research Institute (MRI) located in the Masvingo Province. The two research stations are in different agro-ecological zones (AEZ) (Mugandani et al., 2012). They were purposively selected because they are conservation stations for the two dominant indigenous Sanga cattle breeds of Tuli and Mashona. Grasslands Research Institute is located $67 \mathrm{~km}$ southeast of the capital Harare in agro-ecological zone IIa, which receives a mean annual rainfall of $750-1000 \mathrm{~mm}$ with an average daily temperature of $15-25^{\circ} \mathrm{C}$. Makoholi Research Institute is located $250 \mathrm{~km}$ south of the capital Harare in agro-ecological zone IV, some $40 \mathrm{~km}$ north of the city of Masvingo. The area is semi-arid receiving a mean annual rainfall of 450$650 \mathrm{~mm}$ and experiencing average daily temperatures of $15-25^{\circ} \mathrm{C}$. 


\subsection{Sampling Procedure and Data Collection}

Monthly live weight records from 2011 to 2015 were collected from GRI for Tuli cattle and MRI for Mashona cattle. The records were collected for a beef herd average annual production (AAP) of 450 animals and 500 animals for Grasslands Research Institute and Makoholi Research Institute respectively. The data collected covered five classes of animals: cows (216), bulls (29), heifers (65), steers (42) and calves (60) from GRI and cows (206), bulls (28), heifers (65), steers (50) and calves (57) from MRI. Data was sampled for six live weight measurements per animal per year for each sub-category with two live weight measurements representing three distinct seasons; hot wet (December to March), cold dry (April to July) and hot dry (August to November).

\subsection{Animals and Feed Characterization}

Live weight data collected across the different seasons for the sampled animals were used to estimate average daily weight gain or loss. Seasonal average daily weight gain or loss was calculated as seasonal live weight changes divided by the number of days across the season. The seasonal daily weight gain or losses were averaged to estimate the average daily weight gain or loss per animal per year. Metabolic body weight was calculated using the following equation according to Kumar et al. (2016):

$M B W=L W^{0.75}$

Where MBW is the metabolic body weight in $\mathrm{kg}$ and LW is the live weight in $\mathrm{kg}$.

Forage digestibility estimation was based on proximate analysis data (Table 1) from a research by Tavirimirwa et al. (2012). The dry matter digestibility was estimated using the equation according to FAO (2012).

$D M D=88.9-(0.77 * \% A D F)$

Where DMD is dry matter digestibility and ADF is the acid detergent fibre content. 


\subsection{Estimating Energy Requirements}

The estimations of enteric methane emissions were based on the calculations of net energy components using the algorithms detailed in the IPCC guidelines (IPCC, 2006, IPCC, 2019). The estimated net energy requirements were calculated for maintenance, activity, growth and pregnancy (cows). Gross energy intake and estimated dry matter intake were then calculated using the component net energy requirements, and estimated dry matter digestibility.

\subsubsection{Estimation of net energy requirements for maintenance $\left(\mathrm{NE}_{\mathrm{m}}\right)$}

Net energy requirements for maintenance (NEm) were calculated based on the live body weight of the animal according to the following equation:

$N E_{m}=C f i * L W^{0.75}$

Where:

$\mathrm{NEm}=$ net energy required by the animal for maintenance, $\mathrm{MJ}$ day $^{-1}$

$C f i=$ maintenance energy coefficient and varies across sub-categories $(0.322$ for calves, heifers and steers, 0.386 for cows and 0.370 for bulls), $\mathrm{MJday}^{-1} \mathrm{~kg}^{-1}$

LW = animal live weight, $\mathrm{kg}$

\subsubsection{Estimation of net energy requirements for activity $\left(\mathrm{NE}_{\mathrm{a}}\right)$}

Net energy requirements for activity (NEa) were calculated based on the maintenance energy requirements $(\mathrm{NEm})$ with an activity coefficient assigned to the animal depending on the feeding situation. The calculation was done using the following equation:

$N E_{a}=C_{a} * N E_{m}$

Where:

$\mathrm{NEa}=$ net energy for animal activity, $\mathrm{MJday}^{-1}$ 
$162 C a=$ animal activity coefficient corresponding to the feeding situation

$163 \mathrm{NEm}=$ net energy for maintenance, $\mathrm{MJ}_{\text {day }^{-1}}$

\subsubsection{Estimation of net energy requirements for growth $\left(\mathrm{NE}_{\mathrm{g}}\right)$}

165 Net energy requirements for growth were calculated based on average animal live weight, 166 average daily weight gain and breed mature weight. The calculation was done according to 167 the following equation:

168 $N E_{g}=22.02 *\left(\frac{B W}{C} * M W\right) * W G^{1.097}$

169 Where:

$170 \mathrm{NEg}=$ net energy for growth, $\mathrm{MJ}$ day $^{-1}$

$171 \mathrm{BW}=$ average live body weight, $\mathrm{kg}$

$172 \mathrm{C}=$ sub-category growth coefficient with a value of 0.8 for females, 1.0 for steers and 1.2 for 173 bulls

174 MW = mature live body weight of an adult animal in moderate body condition for a specific 175 breed, $\mathrm{kg}$

$176 \mathrm{WG}=$ average daily weight gain, $\mathrm{kg} \mathrm{day}^{-1}$

\section{$177 \quad 2.4 .4$ Estimation of net energy requirements for pregnancy $\left(\mathrm{NE}_{\mathrm{p}}\right)$}

178 Net energy requirements for pregnancy were calculated for cows and were estimated as a 179 fraction of the net energy requirements for maintenance according to the following equation:

$N E_{p}=C_{\text {pregnancy }} * N E_{m}$

181 Where: 
$\mathrm{NEp}=$ net energy for pregnancy, $\mathrm{MJ}$ day $^{-1}$

$\mathrm{NEm}=$ net energy for maintenance, $\mathrm{MJ}$ day $^{-1}$

\subsubsection{Estimation of the ratios of the net energy available in the diet for maintenance} and growth to digestible energy consumed (REM and REG)

Intermediate values in respect of the ratio of net energy available in the diet for maintenance

$R E M=1.123-\left(4.092 * 10^{-3} * D E \%\right)+\left[1.123 * 10^{-5} * D E \%^{2}\right]-\left(\frac{25.4}{D E \%}\right)$

Where:

193

$\mathrm{REM}=$ ratio of net energy available in the diet for maintenance to digestible energy consumed

$\mathrm{DE} \%=$ dry matter digestibility, $\%$

$$
R E G=1.164-\left(5.160 * 10^{-3} * D E \%\right)+\left[1.308 * 10^{-5} * D E \%^{2}\right]-\left(\frac{37.4}{D E \%}\right)
$$

197 Where: 
204

\subsubsection{Estimation of gross energy intake (GEI)}

Gross energy intake was calculated using the different components of the net energy requirements and the REM and REG ratios according to the following equation (IPCC, 2006, IPCC, 2019):

$$
G E=\frac{\left[\left(N E_{m}+N E_{a}+N E_{p}\right) \div R E M+\left(\frac{N E_{g}}{R E G}\right)\right]}{\frac{D E \%}{100}}
$$

\section{Where:}

$\mathrm{GE}=$ gross energy intake for the animal, $\mathrm{MJ}$ day $^{-1}$

$\mathrm{NEm}=$ net energy for maintenance, $\mathrm{MJ}$ day $^{-1}$

$\mathrm{NEa}=$ net energy for animal activity, $\mathrm{MJ}_{\text {day }^{-1}}$

$\mathrm{NEp}=$ net energy for pregnancy, $\mathrm{MJ}$ day $^{-1}$

REM = ratio of net energy available in the diet for maintenance to digestible energy consumed

$\mathrm{NEg}=$ net energy for growth, $\mathrm{MJ}$ day $^{-1}$

REG $=$ ratio of net energy available for growth in the diet to digestible energy consumed

$$
\mathrm{DE} \%=\text { dry matter digestibility }
$$

\subsubsection{Estimating dry matter intake (DMI)}

Once the values for gross energy intake were estimated for each animal in each animal subcategory, the dry matter intake in kilograms of dry matter per day $\left(\mathrm{kg} \mathrm{day}^{-1}\right)$ was also calculated. To convert gross energy intake in energy units to dry matter intake (DMI), the gross energy intake was divided by the estimated energy density of the feed (IPCC, 2006, IPCC, 2019). A default value of $18.45 \mathrm{MJ} \mathrm{kg}^{-1}$ of dry matter was used for the energy density. 


\subsubsection{Estimating enteric methane emission factor (EF)}

222 Emission factors for enteric fermentation for each animal sub-category were calculated based

223

224

225

226

227

228

229 Where:

$230 \mathrm{Ym}=$ enteric methane conversion factor, $\%$

231 ADFI = acid detergent fibre intake, $\mathrm{kg} \mathrm{day}^{-1}$

$232 \mathrm{DMI}=$ dry matter intake, $\mathrm{kg} \mathrm{day}^{-1}$

The sub-category enteric methane emission factors were then calculated using the following 234 equation:

$235 \quad E F=\frac{G E I *\left(\frac{Y m}{100}\right) * 365}{55.65}$

236 Where:

$237 \mathrm{EF}=$ emission factor, $\mathrm{kg} \mathrm{CH} 4$ head $^{-1} \mathrm{year}^{-1}$

238 GEI = gross energy intake, $\mathrm{MJ}_{\text {head }}{ }^{-1}$ day $^{-1}$

$239 \mathrm{Ym}=$ methane conversion factor which is the percentage of gross energy in feed converted to 240 methane, $\%$ 
$24155.65=$ the energy content of methane, $\mathrm{MJ} \mathrm{kg}^{-1} \mathrm{CH} 4$

$242 \quad 2.4 .9$ Calculations

243 Other measures of enteric methane emission that were calculated included daily methane

244 production $\left(\mathrm{gCH}_{4} \mathrm{day}^{-1}\right)$, methane energy loss (MJ/day), methane yield $\left(\mathrm{g} \mathrm{CH}_{4} \mathrm{~kg}^{-1} \mathrm{DMI}\right)$ and 245 enteric methane emission intensities $\left(\mathrm{gCH}_{4} / \mathrm{kg} \mathrm{LW}\right.$ and $\mathrm{kg} \mathrm{CO}_{2}$-eq/kg LW). Daily methane 246 production (DMP) was calculated using the following equation:

$247 D M P=\frac{E F * 1000}{365}$

248 Where:

$249 \mathrm{DMP}=$ daily methane production, $\mathrm{g} \mathrm{day}^{-1}$

$250 \mathrm{EF}=$ enteric methane emission factor, $\mathrm{kg} \mathrm{CH} 4$ head $^{-1}$ year $^{-1}$

$251365=$ number of days per year

252 Methane energy loss $\left(\mathrm{CH}_{4} \mathrm{E}\right)$ in $\mathrm{MJ} /$ day was calculated by multiplying daily methane 253 production with the energy density for methane $\left(55.65 \mathrm{MJ} / \mathrm{kgCH}_{4}\right)$. Methane yield (MY) was 254 estimated using the following equation:

$255 \quad M Y=\frac{D M P}{D M I}$

256 Where:

$257 \mathrm{MY}=$ methane yield, $\mathrm{g} \mathrm{CH}_{4} \mathrm{~kg}^{-1} \mathrm{DMI}$

258 DMP = daily methane production, $\mathrm{g} \mathrm{day}^{-1}$

259 DMI = dry matter intake, $\mathrm{kg} \mathrm{day}^{-1}$ 
260 Enteric methane emission intensity in grams $\mathrm{CH}_{4}$ per $\mathrm{kg}$ live weight was estimated using the

261 following equation:

$262 E I=\frac{D M P}{L W}$

263 Where:

264 EI = emission intensity, $\mathrm{g} \mathrm{kg}^{-1} \mathrm{LW}$

$265 \mathrm{DMP}=$ daily methane production, $\mathrm{g} \mathrm{CH}_{4} /$ day

266 LW = live weight, $\mathrm{kg}$

267 Enteric methane emission intensity in $\mathrm{kg} \mathrm{CO}_{2}$-eq per $\mathrm{kg}$ live weight was estimated using the 268 following equation according to (FAO, 2015):

$$
E I_{C O 2-e q}=379.0 * L W^{-0}
$$

269

$\mathrm{EI}_{\mathrm{co} 2-\mathrm{eq}}=379.0 *(\mathrm{LW})^{-0.354}$

270 Where:

$271 \mathrm{EI}_{\text {co2-eq }}=$ emission intensity, $\mathrm{kg} \mathrm{CO}_{2}$-eq kg ${ }^{-1} \mathrm{LW}$

$272 \quad$ LW $=$ live weight, $\mathrm{kg}$

\section{$273 \quad 3 \quad$ Statistical Analysis}

274 Data was analysed using TIBCO Statistica Version 13.3.0. Descriptive statistics (mean, 275 standard deviation, standard error of means and 95\% confidence intervals) were calculated 276 for live weight, metabolic body weight, daily weight gain, net energy for maintenance, net 277 energy for activity, net energy for growth, net energy for pregnancy (cows), gross energy 278 intake, dry matter intake, methane conversion factor, methane emission factor, methane yield, 
methane emission intensity, and carbon dioxide equivalent emission intensity. Test of homogeneity of variances was also done. Analysis of Variance (ANOVA) was done at a significance level of $\alpha=0.05$. Differences were tested using the Fisher's Least Significance Difference (LSD) test.

\section{Results}

\subsection{Animal Characterization}

The sampled animals were grouped into five sub-categories according to age and/or sex with expected significant variations in live weight, metabolic body weight and daily weight gain across the animal classes (Table 2). Live weight and corresponding metabolic body weight were not significantly $(\mathrm{P}>0.05)$ different between the two stations for the sub-categories of cows, heifers, steers and calves while live weight and metabolic body weight for Tuli bulls were significantly $(\mathrm{P}<0.05)$ higher than those for Mashona bulls. Daily weight gain was significantly $(\mathrm{P}<0.05)$ different across the five classes for both the Tuli and Mashona breeds. It ranged from $-0.07 \pm 0.009$ to $0.08 \pm 0.001 \mathrm{~kg} /$ day across the Tuli animal classes, and from $0.01 \pm 0.010$ to $0.07 \pm 0.006 \mathrm{~kg} / \mathrm{day}$ across the Mashona animal classes. The average daily weight gain was $-0.02 \pm 0.005 \mathrm{~kg} /$ day and $0.03 \pm 0.006 \mathrm{~kg} / \mathrm{day}$ for Tuli and Mashona respectively. Cows from both research stations had a negative weight gain.

\subsection{Energy Requirements, Dry Matter Intake and Feed Digestibility}

Estimates of net energy requirements generally followed the variations in live weight. Table 3 shows the estimates for net energy requirements for the two breeds of Tuli and Mashona across the five animal sub-categories. Net energy for maintenance and activity were significantly $(\mathrm{P}<0.05)$ different across the five animal classes from both breeds with bulls expectedly having the highest net energy requirements for both maintenance and activity. Cows from both research stations had a negative estimate for net energy requirement for 
growth. Mashona bulls and Mashona heifers and steers had the highest estimate for net energy requirement for growth of about $0.5 \mathrm{MJ} / \mathrm{day}$. Estimate for net energy requirement for pregnancy was not different between the Tuli and Mashona cows (2.2MJ/day).

Estimates for gross energy intake also varied with variations in live weight and these directly affected dry matter intake calculations. Table 4 shows estimates for gross energy and dry matter intake and the estimated dry matter digestibility (DMD) across the five animal subcategories. Both gross energy intake estimates, and dry matter intake estimates were significantly $(\mathrm{P}<0.05)$ different across the five classes. Tuli bulls had the highest gross energy intake and corresponding dry matter intake estimates. Gross energy intake ranged from a low of $41.7 \pm 0.16 \mathrm{MJ} /$ day for Tuli calves to a high of $152.8 \pm 2.72 \mathrm{MJ} /$ day for Tuli bulls. Average dry matter intake estimates as a percentage of live weight was 2.36, 2.19, 2.82 and $3.41 \%$ for cows, bulls, heifers and steers and calves respectively. Dry matter digestibility estimate was calculated at $53.9 \%$.

\subsection{Enteric Methane Emissions}

317 Enteric methane emissions for the two breeds were determined in terms of the seven important emission coefficients namely: methane conversion factor, daily methane production, methane energy loss, methane yield, methane emission factor and methane emission intensity. Table 5 shows the estimated methane conversion factor, daily methane production, methane energy loss and methane yield for the two breeds across the four animal sub-categories. Generally, there were significant $(\mathrm{P}<0.05)$ differences in methane conversion factor, daily methane production, methane energy loss and methane yield across the five animal classes for both breeds. Estimated methane conversion factors ranged from 5.6 to $7.5 \%$ and the estimates were significantly different across the five classes. Estimates for daily methane production increased with increasing live weight (Table 5). Daily methane production ranged from a low of about $56.5 \mathrm{gCH}_{4} /$ day for calves to a high of about 
$153.5 \mathrm{gCH}_{4} /$ day for Tuli bulls. Methane energy loss was significantly different across the four classes ranging from a low of around $2.3 \mathrm{MJ} /$ day for calves to a high of about $8.5 \mathrm{MJ} /$ day for Tuli bulls and was even significantly higher than the energy allocated towards productive components like growth. Estimated methane yield ranged from a low of $18.5 \mathrm{gCH}_{4} / \mathrm{kgDMI}$ for Tuli bulls to a high of $25.0 \mathrm{gCH}_{4} / \mathrm{kgDMI}$ for Tuli calves.

The respective methane emission factors and methane emission intensities for the five animal classes across the two breeds are given in Table 6. The methane emission factors significantly $(\mathrm{P}<0.05)$ varied across animal classes in both Tuli and Mashona breeds. Estimates for both emission intensity and carbon dioxide equivalent emission intensity were also significantly (P $<0.05)$ different across animal classes but generally increased with decreasing live weight.

\section{Discussion}

The IPCC Tier-2 model for estimating enteric methane emissions is a function of a number of animal parameters which include live weight, weight gain, feeding system, sex and productivity (Goopy et al., 2018). These parameters influence cattle energy demand and hence enteric methane production with the level of animal productivity being the most important factor. The results from this study showed that the animal characterization parameters were generally in agreement with reports from other researches but they contributed significantly to the variation in estimated emissions. The live weights for cows from both breeds were generally within the ranges reported by Dzama et al. (1995) of 275 to $350 \mathrm{~kg}$ for Mashona cows and 280 to $468 \mathrm{~kg}$ for Tuli cows. Bull weights were notably lower than the weights reported by Assan (2012b) of 430 to $680 \mathrm{~kg}$ for Mashona bulls and 770 to $800 \mathrm{~kg}$ for Tuli bulls. The differences could be due the variation in production systems under which data was collected. Of the three Zimbabwean Sanga cattle breeds of Mashona, Tuli and Nkone, the Tuli breed is relatively bigger and is a better performing breed with relatively 
higher live weight gains (Assan, 2012a). Live weight is the most important parameter determining absolute enteric methane emissions with higher live weights resulting in higher emissions (Robinson et al., 2014). A bigger animal has a bigger rumen capacity hence higher level of fermentation resulting in higher enteric methane production. Scholtz (2016) reported daily weight gains of $0.05 \pm 0.11$ and $0.09 \pm 0.06 \mathrm{~kg} /$ day for Afrikander and Mashona steers and these were not very different from the daily weight gain estimates for heifers and steers from this study. The observed negative weight gain in cows across both breeds could be an indication that cows are mostly in negative energy balance throughout the year, and this is in agreement with a report by Tada et al. (2013). Under tropical production systems, feed is abundant during the wet season with severe scarcity experienced during the dry season resulting in severe weight loss (Peters et al., 2012).

Estimates of net energy requirements for maintenance for cows and bulls were not very different from the net energy requirements of a 300kg live weight animal of between 23.3 to 25.5MJ/day (CSIRO, 2007) although net energy requirements for steers and heifers were significantly lower than the estimates of about $20.3 \mathrm{MJ} /$ day reported by da Fonseca et al. (2019). Azizi et al. (2017) reported estimates for net energy requirement for activity of 4.6MJ/day and this was similar to the estimates for heifers and steers in this study but significantly lower than estimates for both cows and bulls and considerably higher than estimates for calves. Generally, animals under agro-pastoral grazing systems tend to have higher energy requirements for activity as they spend a lot of energy looking for food (Peters et al., 2012). The estimates for net energy requirement for growth obtained from this study were significantly lower than the estimates reported for Zebu bulls, steers and heifers which ranged from $0.93 \mathrm{Mcal} / \mathrm{day}$ to $9.54 \mathrm{Mcal} / \mathrm{day}$ (Marcondes et al., 2010). The lower net energy requirements for growth could be explained by the lower daily weight gains which are a result of lower feed intakes as animals are usually under a restricted feeding system. Net 
energy requirement for pregnancy of $567 \mathrm{Kcal} /$ day $(2.37 \mathrm{MJ} /$ day $)$ at 190 days gestation and $821 \mathrm{Kcal} /$ day $(3.44 \mathrm{MJ} /$ day) at 270days of gestation were reported by Bell et al. (2016). These estimates were comparable to the $2.2 \pm 0.02 \mathrm{MJ} /$ day net energy for pregnancy estimated for both Tuli and Mashona cows.

The gross energy intake estimates for Tuli and Mashona cows and bulls were considerably higher than those reported by Kouazounde et al. (2015) for the Somba, Borgou and Lagune cattle of Benin. These differences could be due to the differences in mature live weight with Benin cattle breeds having a lower mature live weight than the Zimbabwean Sanga breeds. Gross energy intake estimates for both Tuli and Mashona were also comparable to estimates of $42.65 \pm 0.998 \mathrm{MJ} /$ day for calves, $63.75 \pm 0.793 \mathrm{MJ} /$ day for heifers and steers and 131.11 $\pm 4.63 \mathrm{MJ} /$ day for mature males and females reported by Caetano et al. (2018) for Indian beef cattle. Although dry matter intake estimates for both Tuli and Mashona were within the IPCC range of 2-3\% of live weight, they were based on ad libitum feeding, which could not be the case in most African cattle production systems. Both gross energy intake and dry matter intake are important parameters in the estimation of enteric methane emissions using the Tier-2 approach. The dry matter digestibility estimate of $53.9 \%$ was within the range of dry matter digestibility of 39 to $63 \%$ reported for the common grass species of tropical South Africa (du Toit et al., 2018). The dry matter digestibility estimate was also within the range of the IPCC representative digestibility for cattle fed on low quality forage which ranges from 45 to $55 \%$ (IPCC, 2006). The digestibility estimates used for beef cattle Tier-2 enteric methane estimations in Ethiopia which ranged from 53.51 to $53.94 \%$ (Wilkes et al., 2020) were also similar to the estimate obtained from this study. Most cattle production systems in Africa are based on natural veld which tend to have low digestibility during most parts of the year. Low forage digestibility results in high methane conversion factor and high methane yield (Goopy et al., 2014, Ku-Vera et al., 2018). 
Liu et al. (2017) reported estimates of methane conversion factor that ranged from 3.8 for concentrate based diets to 7.4 for forage-based diets. These estimates for forage-based diets were not very different from methane conversion factors estimated for both Tuli and Mashona cattle which ranged from about 5.6 to 7.5. Generally, methane conversion factor increased with decreasing live weight and this could be due to a decrease in dry matter intake with decreasing live weight, which has a bearing on rumen retention time (Hellwing et al., 2016). High methane conversion factors are associated with forage-based diets because of the high levels of acid and neutral detergent fibre which tends to reduce dry matter intake and increase rumen digesta retention time (Lima et al., 2016). A reduction in dry matter intake results in increased rumen retention time thereby giving more time for rumen fermentation and converting more organic matter to methane (Ku-Vera et al., 2018).

Daily methane production for Nguni $(263.8 \pm 31.25 \mathrm{~g} / \mathrm{day})$ and Boran $(301.4 \pm 25.51 \mathrm{~g} / \mathrm{day})$ cows reported by Mapfumo et al. (2018) were considerably higher than estimates for cows obtained from this study. Generally, daily methane production is directly proportional to live weight and dry matter intake (Cottle et al., 2015), and this explains the huge difference between the Nguni and Boran cows and the lower estimates obtained for Tuli and Mashona cows. Methane energy loss of 6.0 to $8.2 \mathrm{MJ} /$ day reported for Thai beef cattle (Yan et al., 2000) were not dissimilar from the estimates for cows and bulls obtained in this study, which ranged from 6.7 to $8.5 \mathrm{MJ} /$ day. Methane energy loss represents a significant loss of gross energy intake (Yan et al., 2000). The estimates for methane yield from this study which ranged from a low of $18.5 \pm 0.00 \mathrm{gCH}_{4} / \mathrm{kgDMI}$ for Tuli bulls to a high of

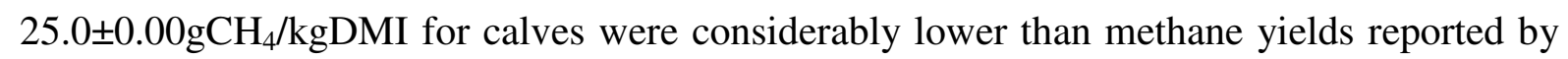
Mapfumo et al. (2018) for Boran and Nguni cows which ranged from a low of $26.5 \pm 1.62 \mathrm{gCH}_{4} / \mathrm{kgDMI}$ to a high of $32.8 \pm 1.32 \mathrm{gCH}_{4} / \mathrm{kgDMI}$. The differences could be due to the different methods used in the estimation where Boran and Nguni estimates were based on 
measurements using the laser methane detector while estimates in the current study were based on the IPCC Tier-2 model. Generally, methane yield tended to increase with decreasing live weight and dry matter intake (Ku-Vera et al., 2018) and this is possibly due to increased rumen retention time with reduced dry matter intakes. A higher dry matter intake increases rumen passage thereby giving less time for fermentation and resulting in reduced methane yield (Goopy et al., 2014, Goopy et al., 2020).

The estimates for methane emission factors for cows, bulls and calves from this study were notably higher than the 2006 IPCC default emission factor of $31 \mathrm{~kg} / \mathrm{head} / \mathrm{year}$. However, estimates for heifers and steers were comparable to the IPCC default emission factor for Africa. Estimated Tier-2 emission factors for Tuli and Mashona cows were 20\% and 30\% higher respectively than the default Tier-1 emission factor for Africa. For bulls, Tier-2 emission factors were higher than the Tier-1 emissions factors by $20 \%$ and $30 \%$ for Tuli and Mashona bulls respectively. Estimates for heifers and steers were slightly lower than the Tier1 emission factor differing with the Tier- 1 by a margin of $1 \%$ and $2 \%$ for Tuli and Mashona respectively. Tier-2 estimates for calves were considerably lower than the default Tier-1 emission factor and differing by a margin of $20 \%$ for both Tuli and Mashona calves. Generally, the emission factors for the Tuli and Mashona cattle generated using the IPCC Tier-2 model were notably different from the IPCC default emission factors for Africa. Emission factors reported by Goopy et al. (2018) were comparable to those estimated from this study for heifers and steers but significantly lower than those from this study for cows, bulls and calves. Goopy et al. (2018) reported emission factors of 26.7-34.1kg/head/year for cows, $34.1-37.4 \mathrm{~kg} / \mathrm{head} / \mathrm{year}$ for bulls, $23.0-31.7 \mathrm{~kg} / \mathrm{head} / \mathrm{year}$ for heifers, 27.8 $34.5 \mathrm{~kg} / \mathrm{head} /$ year for steers and $13.9-18.1 \mathrm{~kg} / \mathrm{head} /$ year for calves. The differences in emission factors can be explained in terms of differences in live weight which is an important factor in determining levels of enteric methane emissions. Live weight determines gross energy intake 
which in turn affects enteric methane emission estimates. Estimates for methane emission intensity for calves from this study were comparable to those reported by Mapfumo et al.

455

456

457 (2018) which ranged from $0.7 \pm 0.05$ to $1.0 \pm 0.04 \mathrm{gCH}_{4} / \mathrm{LW}$ for Nguni and Boran cows. However, emission intensities for the other animal classes across the two breeds were relatively lower than those reported for the Nguni and Boran cows (Mapfumo et al., 2018). Generally, emission intensity is inversely related to live weight and level of production with lower live weights and low input production systems having high emission intensities (Garg et al., 2018, Samsonstuen et al., 2020). Carbon dioxide equivalent emission intensities estimated for Tuli and Mashona cattle were significantly higher than those reported for beef cattle in Uruguay where reported carbon dioxide equivalent emission intensities under rangeland conditions were estimated at $24.8 \mathrm{kgCO}_{2} \mathrm{eq} / \mathrm{kgLW}$ to $41 \mathrm{kgCO}_{2} / \mathrm{kgLW}$ (Becoña et al., 2014). Emission intensity per kg live weight is generally lower as production system intensifies, with the highest values for low-input systems and lowest values under intensive fattening systems (Garg et al., 2018). Emission intensities are high at lower live weight because emissions are spread over a smaller body size (Samsonstuen et al., 2020, Velazco et al., 2017) and this explains the high emission intensities in low production systems especially in Sub-Saharan Africa, Asia and Latin America. Accurately characterising emissions using country specific parameters will help explain the spatial variation in emissions across countries and regions.

\section{Conclusions}

Both Tuli and Mashona breed showed no significant differences in estimated enteric methane emissions. This study concluded that enteric methane emission factors estimated using the IPCC Tier-2 model offer insights into the controversial use of the default IPCC Tier-1 emission factors. The use of country specific animal parameters will result in the generation of more representative emission estimates which in turn will help in producing accurate 
emission inventories. Based on the results from this study, the estimated emission factors for bulls and cows were higher than the default IPCC Tier-1 emission factors while those for calves were considerably lower than the default IPCC Tier-1 emissions factors. Estimated emission factors for heifers and steers were within range of the default Tier-1 emission factors. It can therefore be concluded that the default Tier-1 emission factors underestimate emission factors for certain animal classes while overestimating for others making them generally less representative. The methane emission factors estimated in this study will provide a baseline for improved beef cattle enteric methane emission inventories in

Zimbabwe.

\section{Acknowledgements}

The authors thank research officers from Grassland Research Institute and Makoholi

Research Institute for the support during data collection.

\section{Declarations}

\section{$491 \quad$ Funding}

492 This work was financially supported by Chinhoyi University of Technology through the Staff

\section{Conflicts of interest}

The authors declare no competing interests.

\section{Ethics approval (include appropriate approvals or waivers)}

All procedures performed in the study were in accordance with the ethical standards of the Chinhoyi University of Technology research committee.

\section{Consent to participate}

All researchers were informed of the risks and benefits involved.

\section{Consent for publication}

All authors give consent for the publication of details within the text to be published in the Tropical Animal Health and Production journal

\section{Availability of data and material}

All data and materials used in the study can be accessed

\section{Code availability}

Not applicable 


\section{Authors' contributions}

514 1. Conception of the work - Showman Gwatibaya

515 2. Data collection - Showman Gwatibaya, Accadius Tinarwo Tigere and Bosiwe Tererai

516 3. Data analysis and interpretation - Chrispen Murungweni

517 4. Drafting the article - Showman Gwatibaya

518 5. Critical revision of the article - Raphael Jingura

519 6. Final approval of the version to be published - Irvine Mpofu

520

521

522

523

524

525

526

527

528

529

530

531

532

533

534

535

536

537 
ABDELRAHMAN, S. M. \& LOU, Y. 2015. Some Approaches for Reducing Methane Emissions from Ruminants. Animal Environment and Welfare.

AGRAWAL, D. \& KAMRA, D. Global warming: Role of livestock and mitigation strategies. International conference on "Physiological capacity building in livestock under changing climate scenario". Physiology and Climatology division, Indian Veterinary Research Institute, Izatnagar, 2010. 73-80.

ALLIEVI, F., ANTONELLI, M., DEMBSKA, K. \& PRINCIPATO, L. 2019. Understanding the Global Food System. Achieving the Sustainable Development Goals Through Sustainable Food Systems. Springer.

ASSAN, N. 2012a. Genetic improvement and utilization of indigenous cattle breeds for beef production in Zimbabwe: Past, present and future prospects. Scientific Journal of Agricultural, 1, 1-13.

ASSAN, N. 2012b. Genetic parameters estimation and trends for birth weight in cattle. Journal of Animal Science Advances, 2, 274-281.

AZIZI, A., MARDHATI, M., MOHD FAIRUZ, M., SHAIDATUL AZDAWIYAH, A., NURUL AIN, A., FAUZI, J., MOHAMAD HARIZ, A. \& REISINGER, A. 2017. Local emission factors estimates for methane emission from cattle enteric fermentation using IPCC tier-2 methodology. Mal. J. Anim. Sci, 20, 1-10.

BANNINK, A., SCHIJNDEL, M. \& DIJKSTRA, J. A research model of enteric fermentation in dairy cows applied as Tier 3 to estimate methane emission for the Dutch National Inventory Report. 4th international conference on greenhouse gases and animal agriculture, Banff, Canada, 2010. Greenhouse Gases and Animal Agriculture, 158-158.

BANNINK, A., VAN SCHIJNDEL, M. \& DIJKSTRA, J. 2011. A model of enteric fermentation in dairy cows to estimate methane emission for the Dutch National Inventory Report using the IPCC Tier 3 approach. Animal Feed Science and Technology, 166, 603-618.

BECOÑA, G., ASTIGARRAGA, L. \& PICASSO, V. D. 2014. Greenhouse gas emissions of beef cow-calf grazing systems in Uruguay. Sustainable Agriculture Research, 3.

BELL, M., ECKARD, R., MOATE, P. J. \& YAN, T. 2016. Modelling the effect of diet composition on enteric methane emissions across sheep, beef cattle and dairy cows. Animals, 6, 54.

BERNOUX, M. \& WOLF, J. 2017. Regional analysis of the nationally determined contributions of Eastern Africa: gaps and opportunities in the agricultural sectors. Environment and Natural Resources Management. Working Paper (FAO) eng no. 67.

BHATTA, R. \& ENISHI, O. 2007. Measurement of methane production from ruminants. Asianaustralasian journal of animal sciences, 20, 1305-1318.

BHATTA, R., MALIK, P., PRASAD, C. \& BHATTA, R. 2015. Enteric methane emission: status, mitigation and future challenges: an Indian perspective. Livest Prod Climate Change, 229.

BUCCIONI, A., CAPPUCCI, A. \& MELE, M. 2015. Methane emission from enteric fermentation: methanogenesis and fermentation. Climate Change Impact on Livestock: Adaptation and Mitigation. Springer.

CAETANO, M., WILKES, M., PITCHFORD, W., LEE, S. \& HYND, P. 2018. Energy relations in cattle can be quantified using open-circuit gas-quantification systems. Animal Production Science, 58, 1807-1813.

CARO, D., DAVIS, S. J., BASTIANONI, S. \& CALDEIRA, K. 2014. Global and regional trends in greenhouse gas emissions from livestock. Climatic change, 126, 203-216.

CHAUCHEYRAS-DURAND, F. \& OSSA, F. 2014. The rumen microbiome: composition, abundance, diversity, and new investigative tools. The Professional Animal Scientist, 30, 1-12.

CSIRO 2007. Nutrient requirements of domesticated ruminants, CSIRO publishing.

DA FONSECA, M. P., BORGES, A. L. D. C. C., CARVALHO, P. H. D. A., E SILVA, R. R., GONÇÃLVES, L. C., BORGES, I., LAGE, H. F., FERREIRA, A. L., SALIBA, E. O. S. \& JAYME, D. G. 2019. Energy 
partitioning in cattle fed diets based on tropical forage with the inclusion of antibiotic additives. Plos one, 14, e0211565.

DAS, L. K., KUNDU, S., KUMAR, D. \& DATT, C. 2014. Assessment of energy content of some tropical concentrate feeds of ruminants using model of National Research Council-2001. Indian Journal of Science and Technology, 7, 1999.

DE HAAN, C. 2006. Livestock's long shadow. Environmental issues and options Food and Agriculture Organization of the United Nations (FAO) http://www. virtualcentre. org/enlibrary/key_pub/longshad/A0701E00. pdf.

DESSUS, B., LE TREUT, H. \& LAPONCHE, B. 2008. Global warming: the significance of methane.

DHOUBHADEL, S. P., TAHERIPOUR, F. \& STOCKTON, M. C. 2016. Livestock Demand, Global Land Use Changes, and Induced Greenhouse Gas Emissions. Journal of Environmental Protection, 7, 985.

DONG, H., MANGINO, J., MCALliSTER, T., HATFIELD, J., JOHNSON, D., LASSEY, K., LIMA, M. \& ROMANOVSKAYA, D. 2006. Intergovernmental Panel on Climate Change (IPCC) Guidelines for National Greenhouse Gas Inventories, Volume 4: Agriculture, Forestry and Other Land Use, Chapter 10: Emissions from Livestock and Manure Management. Kanagawa, Japan, 187.

DORAN, P. T. \& ZIMMERMAN, M. K. 2009. Examining the scientific consensus on climate change. Eos, Transactions American Geophysical Union, 90, 22-23.

DU TOIT, C., VAN NIEKERK, W., MEISSNER, H., ERASMUS, L. \& MOREY, L. 2018. Nutrient composition and in vitro methane production of sub-tropical grass species in transitional rangeland of South Africa. The Rangeland Journal, 40, 1-8.

DZAMA, K., NGWERUME, F. \& BHEBHE, E. 1995. Proceedings of the international symposium on livestock production through animal breeding and genetics, 10-11 May 1995.

EGGLESTON, S., BUENDIA, L., MIWA, K., NGARA, T. \& TANABE, K. 2006. 2006 IPCC guidelines for national greenhouse gas inventories, Institute for Global Environmental Strategies Hayama, Japan.

ETIOPE, G. 2012. Methane uncovered. Nature Geoscience, 5, 373-374.

EUGÈNE, M., SAUVANT, D., NOZIÈRE, P., VIALLARD, D., OUESLATI, K., LHERM, M., MATHIAS, E. \& DOREAU, M. 2019. A new Tier 3 method to calculate methane emission inventory for ruminants. Journal of environmental management, 231, 982-988.

FAO 2012. Balanced Feeding for Improving Livestock Productivity. FAO Animal Production and Health Paper.

FAO 2015. Estimating Greenhouse Gas Emissions in Agriculture. A manual to Address Data Requirements for Developing Countries. Food and Agricultural Organization of the United Nations, 1.

FAWZY, S., OSMAN, A. I., DORAN, J. \& ROONEY, D. W. 2020. Strategies for mitigation of climate change: a review. Environmental Chemistry Letters, 1-26.

FERRELL, C. \& OLTJEN, J. 2008. ASAS Centennial Paper: Net energy systems for beef cattleConcepts, application, and future models. Journal of Animal Science, 86, 2779-2794.

GARG, M., SHERASIA, P., PHONDBA, B. \& MAKKAR, H. P. 2018. Greenhouse gas emission intensity based on lifetime milk production of dairy animals, as affected by ration-balancing program. Animal Production Science, 58, 1027-1042.

GOOPY, J. P., DONALDSON, A., HEGARTY, R., VERCOE, P. E., HAYNES, F., BARNETT, M. \& ODDY, V. H. 2014. Low-methane yield sheep have smaller rumens and shorter rumen retention time. British Journal of Nutrition, 111, 578-585.

GOOPY, J. P., KORIR, D., PELSTER, D., ALI, A., WASSIE, S. E., SCHLECHT, E., DICKHOEFER, U., MERBOLD, L. \& BUTTERBACH-BAHL, K. 2020. Severe below-maintenance feed intake increases methane yield from enteric fermentation in cattle. British Journal of Nutrition, 123, 1239-1246. 
GOOPY, J. P., ONYANGO, A., DICKHOEFER, U. \& BUTTERBACH-BAHL, K. 2018. A new approach for improving emission factors for enteric methane emissions of cattle in smallholder systems of East Africa-Results for Nyando, Western Kenya. Agricultural systems, 161, 72-80.

GORORO, E., MAKUZA, S. M., CHATIZA, F. P., GWATIBAYA, S., GAHADZIKWA, P. \& CHIDZWONDO, F. 2017. The potential of reproductive technologies in breeding smallholder cattle populations in Zimbabwe. International Journal of Livestock Production, 8, 168-179.

GROSSI, G., GOGLIO, P., VITALI, A. \& WILLIAMS, A. G. 2019. Livestock and climate change: impact of livestock on climate and mitigation strategies. Animal Frontiers, 9, 69-76.

GUPTA, M., MONDAL, T., LOKESHA, E., SINGH, A., ASHWIN, K., PERWEEN, S. \& SAHOO, J. K. 2018. Methane Emission by Ruminants and Its Measurement-A Review. Int. J. Curr. Microbiol. App. Sci, 7, 3120-3126.

HENNING, B. 2011. Standing in Livestock's "Long Shadow": The Ethics of Eating Meat on a Small Planet. Ethics \& the Environment, 16, 63-93.

HERRERO, M., HENDERSON, B., HAVLÍK, P., THORNTON, P. K., CONANT, R. T., SMITH, P., WIRSENIUS, S., HRISTOV, A. N., GERBER, P. \& GILL, M. 2016. Greenhouse gas mitigation potentials in the livestock sector. Nature Climate Change, 6, 452-461.

HERRERO, M., WIRSENIUS, S., HENDERSON, B., RIGOLOT, C., THORNTON, P., HAVLÍK, P., DE BOER, I. \& GERBER, P. J. 2015. Livestock and the environment: what have we learned in the past decade? Annual Review of Environment and Resources, 40, 177-202.

HIRAISHI, T., KRUG, T., TANABE, K., SRIVASTAVA, N., BAASANSUREN, J., FUKUDA, M. \& TROXLER, T. 2014. 2013 supplement to the 2006 IPCC guidelines for national greenhouse gas inventories: Wetlands. IPCC, Switzerland.

HOOK, S. E., WRIGHT, A.-D. G. \& MCBRIDE, B. W. 2010. Methanogens: methane producers of the rumen and mitigation strategies. Archaea, 2010.

IPCC 2006. Chapter 10. Emissions from Livestock and Manure Management. In 2006 IPCC Guidelines for National Greenhouse Gas Inventories. Volume 4: Agriculture, Forestry and Other Land Use, 4, 10.1-10.87.

IPCC 2019. Task Force on National Greenhouse Gas Inventories. Intergovernmental Panel on Climate Change.

KAEWPILA, C. \& SOMMART, K. 2016. Development of methane conversion factor models for Zebu beef cattle fed low-quality crop residues and by-products in tropical regions. Ecology and evolution, 6, 7422-7432.

KELLIHER, F., CLARK, H., SMITH, M., LASSEY, K. \& SEDCOLE, R. 2009. Reducing uncertainty of the enteric methane emissions inventory. A report prepared for the New Zealand Ministry of Agriculture and Forestry, Wellington.

KHOMBE, C., HAYES, J., CUE, R. \& WADE, K. 1995. Estimation of direct additive and maternal additive genetic effects for weaning weight in Mashona cattle of Zimbabwe using an individual animal model. Animal Science, 60, 41-48.

KOUAZOUNDE, J., GBENOU, J., BABATOUNDE, S., SRIVASTAVA, N., EGGLESTON, S., ANTWI, C., BAAH, J. \& MCALLISTER, T. 2015. Development of methane emission factors for enteric fermentation in cattle from Benin using IPCC Tier 2 methodology. animal, 9, 526-533.

KU-VERA, J. C., VALENCIA-SALAZAR, S. S., PIÑEIRO-VÁZQUEZ, A. T., MOLINA-BOTERO, I. C., ARROYAVE-JARAMILLO, J., MONTOYA-FLORES, M. D., LAZOS-BALBUENA, F. J., CANUL-SOLÍS, J. R., ARCEO-CASTILLO, J. I. \& RAMÍREZ-CANCINO, L. 2018. Determination of methane yield in cattle fed tropical grasses as measured in open-circuit respiration chambers. Agricultural and forest meteorology, 258, 3-7.

KUMAR, S., PUNIYA, A. K., PUNIYA, M., DAGAR, S. S., SIROHI, S. K., SINGH, K. \& GRIFFITH, G. W. 2009. Factors affecting rumen methanogens and methane mitigation strategies. World Journal of Microbiology and Biotechnology, 25, 1557-1566. 
KUMAR, S., SINGH, S., PANDEY, P., KUMAR, N. \& HOODA, O. 2016. Estimation of metabolic heat production and methane emission in Sahiwal and Karan Fries heifers under different feeding regimes. Veterinary world, 9, 496.

LENKA, S., LENKA, N., SEJIAN, V. \& MOHANTY, M. 2015. Contribution of agriculture sector to climate change. Climate Change Impact on Livestock: Adaptation and Mitigation. Springer.

LIMA, A. R. C., FERNANDES, M. H. M. D. R., TEIXEIRA, I. A. M. D. A., FRIGHETTO, R. T. S., BOMPADRE, T. F. V., BIAGIOLI, B., MEISTER, N. C. \& RESENDE, K. T. D. 2016. Effects of feed restriction and forage: concentrate ratio on digestibility, methane emission, and energy utilization by goats. Revista Brasileira de Zootecnia, 45, 781-787.

LIU, Z., LIU, Y., SHI, X., WANG, J., MURPHY, J. P. \& MAGHIRANG, R. 2017. Enteric methane conversion factor for dairy and beef cattle: Effects of feed digestibility and intake level. Transactions of the $A S A B E, 60,459-464$.

MAPFUMO, L., GROBLER, S., MUPANGWA, J., SCHOLTZ, M. \& MUCHENJE, V. 2018. Enteric methane output from selected herds of beef cattle raised under extensive arid rangelands. Pastoralism, 8, 15.

MARCONDES, M. I., CHIZZOTTI, M. L., VALADARES FILHO, S. D. C., GIONBELLI, M. P., PAULINO, P. V. R. \& PAULINO, M. F. 2010. Energy requirements of zebu beef cattle. Nutrient requirements of Zebu beef cattle, BR. Corte. 2nd ed. Federal University of Vicosa, MG, 81-106.

MILNE, A. E., GLENDINING, M. J., BELLAMY, P., MISSELBROOK, T., GILHESPY, S., CASADO, M. R., HULIN, A., VAN OIJEN, M. \& WHITMORE, A. P. 2014. Analysis of uncertainties in the estimates of nitrous oxide and methane emissions in the UK's greenhouse gas inventory for agriculture. Atmospheric Environment, 82, 94-105.

MITLOEHNER, F. M. \& PLACE, S. E. 2011. Clearing the air on livestock and climate change The FAO's" Livestock's Long Shadow" shrinks dramatically in new estimates. Hoard's Dairyman, 156, 51.

MOHAJAN, H. K. Greenhouse gas emissions, Global warming and climate change. 15th Chittagong Conference on Mathematical Physics, 2017. Jamal Nazrul Islam Research Centre for Mathematical and Physical Sciences (JNIRCMPS), 2017. 3.

MUGANDANI, R., WUTA, M., MAKARAU, A. \& CHIPINDU, B. 2012. Re-classification of agro-ecological regions of Zimbabwe in conformity with climate variability and change. African Crop Science Journal, 20, 361-369.

OPIO, C., GeRBER, P., MOTTET, A., FALCUCCI, A., TEMPIO, G., MACLEOD, M., VellingA, T., HENDERSON, B. \& STEINFELD, H. 2013. Greenhouse gas emissions from ruminant supply chains-A global life cycle assessment, Food and agriculture organization of the United Nations.

OTENYO, S. M. 2015. Greenhouse Gas, Climate Change and Carbon Sequestration: Overview and General Principles. Climate Change Impact on Livestock: Adaptation and Mitigation. Springer.

PARRA, A. S. \& MORA-DELGADO, J. 2019. Emission factors estimated from enteric methane of dairy cattle in Andean zone using the IPCC Tier-2 methodology. Agroforestry Systems, 93, 783-791.

PASHAEI, S., RAZMAZAR, V. \& MIRSHEKAR, R. 2010. Digestion of a Feedstuff in the Rumen. Journal of Biological Sciences, 10, 573-580.

PENMAN, J., GYTARSKY, M., HIRAISHIL, T., IRVING, W. \& KRUG, T. 2006. IPCC Guidelines for National Greenhouse Gas Inventories: overview. IPCC Guidelines for National Greenhouse Gas Inventories, 1-12.

POPOVA, M., MORGAVI, D. \& MARTIN, C. 2013. Methanogens and methanogenesis in the rumens and ceca of lambs fed two different high-grain-content diets. Applied and environmental microbiology, 79, 1777-1786.

POWERS, W., AUVERMANN, B., COLE, N. A., GOOCH, C., GRANT, R., HATFIELD, J., HUNT, P., JOHNSON, K., LEYTEM, A. \& LIAO, W. 2014. Quantifying greenhouse gas sources and sinks in animal production systems. Quantifying Greenhouse Gas Fluxes in Agriculture and Forestry: Methods for Entity-Scale Inventory. Technical Bulletin Number 1939. Citeseer. 
RAMSAY, K. 2010. Adaptive traits of Sanga cattle: Their importance in meeting the challenges associated with climate change in the tropics and sub tropics. Advances in Animal Biosciences, 1, 381-382.

REISINGER, A. \& CLARK, H. 2018. How much do direct livestock emissions actually contribute to global warming? Global change biology, 24, 1749-1761.

REYNOLDS, L. 2013. Agriculture and livestock remain major sources of greenhouse gas emissions. World Watch Institute.

RIPPLE, W. J., SMITH, P., HABERL, H., MONTZKA, S. A., MCALPINE, C. \& BOUCHER, D. H. 2014. Ruminants, climate change and climate policy. Nature climate change, 4, 2-5.

SAMSONSTUEN, S., ÅBY, B. A., CROSSON, P., BEAUCHEMIN, K. A., WETLESEN, M. S., BONESMO, H. \& AASS, L. 2020. Variability in greenhouse gas emission intensity of semi-intensive suckler cow beef production systems. Livestock Science, 104091.

SCHOLTZ, M. 2016. Environmental benefits of Afrikaner cow productivity: livestock. Farmer's Weekly, 2016, 44-46.

SHIBATA, M. \& TERADA, F. 2010. Factors affecting methane production and mitigation in ruminants. Animal Science Journal, 81, 2-10.

STEINFELD, H. \& GERBER, P. 2010. Livestock production and the global environment: Consume less or produce better? Proceedings of the National Academy of Sciences, 107, 18237-18238.

STEINFELD, H., GERBER, P., WASSENAAR, T., CASTEL, V., ROSALES, M., DE HAAN, C. \& SHADOW, L. S. L. 2006. Environmental issues and options. Food and Agriculture Organization, Rome, Italy.

SVINURAI, W., MAPANDA, F., SITHOLE, D., MOYO, E. N., NDIDZANO, K., TSIGA, A. \& ZHAKATA, W. 2018. Enteric methane emissions and their response to agro-ecological and livestock production systems dynamics in Zimbabwe. Science of The Total Environment, 616, 710-719.

TADA, O., MUCHENJE, V. \& DZAMA, K. 2013. Preferential traits for breeding Nguni cattle in low-input in-situ conservation production systems. Springerplus, 2, 195.

TAVIRIMIRWA, B., MANZUNGU, E. \& NCUBE, S. 2012. The evaluation of dry season nutritive value of dominant and improved grasses in fallows in Chivi district, Zimbabwe. Online J. Anim. Feed Res, 2, 470-474.

TONGWANE, M. I. \& MOELETSI, M. E. 2018. A review of greenhouse gas emissions from the agriculture sector in Africa. Agricultural systems, 166, 124-134.

TUBIELLO, F., CÓNDOR-GOLEC, R., SALVATORE, M., PIERSANTE, A., FEDERICI, S., FERRARA, A., ROSSI, S., FLAMMINI, A., CARDENAS, P. \& BIANCALANI, R. 2015. Estimating greenhouse gas emissions in agriculture: a manual to address data requirements for developing countries. Estimating greenhouse gas emissions in agriculture: a manual to address data requirements for developing countries.

TUBIELLO, F., SALVATORE, M., CÓNDOR GOLEC, R., FERRARA, A., ROSSI, S., BIANCALANI, R., FEDERICI, S., JACOBS, H. \& FLAMMINI, A. 2014. Agriculture, forestry and other land use emissions by sources and removals by sinks. Statistics Division, Food and Agriculture Organization, Rome.

VELAZCO, J., HERD, R. M., COTTLE, D. \& HEGARTY, R. 2017. Daily methane emissions and emission intensity of grazing beef cattle genetically divergent for residual feed intake. Animal Production Science, 57, 627-635.

WHEELER, T. \& VON BRAUN, J. 2013. Climate change impacts on global food security. Science, 341, 508-513.

WILKES, A., WASSIE, S. E., TADESSE, M., ASSEFA, B., ABU, M., KETEMA, A. \& SOLOMON, D. 2020. Inventory of greenhouse gas emissions from cattle, sheep and goats in Ethiopia (1994-2018) calculated using the IPCC Tier 2 approach.

YAN, T., AGNEW, R., GORDON, F. \& PORTER, M. 2000. Prediction of methane energy output in dairy and beef cattle offered grass silage-based diets. Livestock Production Science, 64, 253-263. 
COTTLE, D., VELAZCO, J., HEGARTY, R. \& MAYER, D. 2015. Estimating daily methane production in individual cattle with irregular feed intake patterns from short-term methane emission measurements. Animal, 9, 1949-1957.

GOOPY, J. P., ONYANGO, A., DICKHOEFER, U. \& BUTTERBACH-BAHL, K. 2018. A new approach for improving emission factors for enteric methane emissions of cattle in smallholder systems of East Africa-Results for Nyando, Western Kenya. Agricultural systems, 161, 72-80.

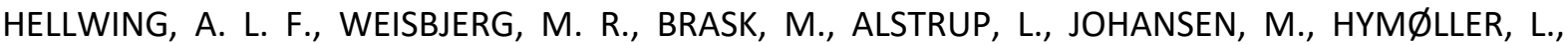
LARSEN, M. K. \& LUND, P. 2016. Prediction of the methane conversion factor (Ym) for dairy cows on the basis of national farm data. Animal Production Science, 56, 535-540.

KOUAZOUNDE, J., GBENOU, J., BABATOUNDE, S., SRIVASTAVA, N., EGGLESTON, S., ANTWI, C., BAAH, J. \& MCALLISTER, T. 2015. Development of methane emission factors for enteric fermentation in cattle from Benin using IPCC Tier 2 methodology. animal, 9, 526-533.

MAPFUMO, L., GROBLER, S., MUPANGWA, J., SCHOLTZ, M. \& MUCHENJE, V. 2018. Enteric methane output from selected herds of beef cattle raised under extensive arid rangelands. Pastoralism, 8, 15.

PETERS, M., RAO, I. M., FISHER, M. J., SUBBARAOA, G. V., MARTENS, S., HERRERO, G., TIEMANN, T. T., AYARZA, M. A. \& HYMAN, G. 2012. Tropical forage-based systems to mitigate greenhouse gas emissions. Centro Internacional de Agricultura Tropical (CIAT).

ROBINSON, D. L., GOOPY, J. P., DONALDSON, A., WOODGATE, R., ODDY, V. \& HEGARTY, R. 2014. Sire and liveweight affect feed intake and methane emissions of sheep confined in respiration chambers. Animal, 8, 1935-1944.

YAN, T., AGNEW, R., GORDON, F. \& PORTER, M. 2000. Prediction of methane energy output in dairy and beef cattle offered grass silage-based diets. Livestock Production Science, 64, 253-263. 